\title{
Road erosion estimation equations derived using a WEPP database
}

\author{
Susan R. Graves \\ Civil Engineer \\ Nez Perce National Forest \\ Grangeville, ID
}

\author{
William J. Elliot \\ Project Leader \\ Rocky Mountain Research Station \\ Moscow, ID
}

\section{$\underline{\text { Abstract }}$}

With the growing public use of the national forests, forest engineers, managers, and planners have had the challenge of maintaining extensive road networks, while minimizing the ecological impacts of those road systems on the environment. Properly spacing road drains for soils, topography, and slope conditions can reduce erosion from road surfaces, subsequently reducing sedimentation risk elsewhere. Knowledge about the amount of soil eroded and delivered from the road system is valuable when making decisions about road drainage design or redesign.

The Water Erosion Prediction Project (WEPP) model, a process based erosion model that can be used to simulate low volume road erosion, was used to create a database of erosion estimates for 72,900 different road configurations, locations, and soil types. This database was then used to derive equations for low volume road erosion and runoff.

A multivariate regression was used to derive equations for road soil loss, road runoff, and sediment yield. The resulting equations provided estimates of road soil loss and road runoff values within $+/-20 \%$ of the original database values. This approach was also attempted for sediment delivery across a buffer with less success. This is possibly due to complications from antecedent moisture conditions, vegetative cover, and sediment loading in runoff.

\section{Introduction}

Forest roads are an integral part of forest management, timber harvesting, fire suppression, and recreation programs. Research has shown that low-volume roads can be sources of erosion and excess sediment in forest aquatic systems. Because of the increasing concerns for water quality and aquatic habitat, the need to quantify the volume of erosion, compare mitigation procedures, and predict the volume of sediment that is transported downslope or into stream systems has increased. By addressing these issues, plans can be made to implement appropriate drainage and sedimentation controls to protect sensitive areas without over-designing road systems (Burroughs and King, 1989).

Until recently, road engineers and hydrologists have relied on professional judgement to estimate sediment loss when planning, locating, and reconstructing roads. However, the public is demanding that better science be used to manage forest roads. 


\section{Background}

The relationships among road erosion and sedimentation with soil, topography, and climate have not been well defined in the forested environments. Low-volume forest roads usually are constructed of native geologic materials. The bare surfaces of these roads are highly susceptible to erosion. Runoff can cause considerable erosion resulting in ruts and gullies. Excessive runoff also has a greater potential for sediment delivery to stream systems, because it has a large sediment carrying capacity (Tysdal et al. 1999).

Field tests have shown that proper placement for runoff, erosion, and sediment control structures depends on soil type, topography, road dimensions, road aspect, vegetative cover, elevation, and climate (Burroughs and King, 1989; Copstead and Johansen, 1998). In order to develop an environmentally sound design, all of these factors have to be determined for each road configuration.

Due to the site-specific nature of erosion, design standards for erosion control cannot reasonably be specified at a nationwide or statewide level. Although there are many equations and models that have been developed to estimate erosion and sedimentation, many are limited to certain regions, road slopes, or soils. Models that are robust enough to model complex forested scenarios often are difficult to use. The time, effort, and knowledge required to build templates for these models can be excessive.

The WEPP model uses physically based input parameters to estimate infiltration, runoff, interrill erosion, rill erosion, and sediment yield (Flanagan and Livingston, 1995). WEPP simulates erosion for consecutive strips of land that has its own soil vegetation and management type, which makes it a suitable model for a forest road erosion study (Elliot and Hall, 1997). WEPP has been validated for a number of road erosion conditions (Elliot et al., 2000).

\section{Objectives}

The goal of this study was to develop runoff, road erosion, and sediment delivery equations for low-volume road systems. The Water Erosion Prediction Project (WEPP) model was used to generate a database, which was validated for predicted erosion and length of sediment deposition plumes (Morfin et al., 1996; Elliot et al., 2000). This database was used for developing the regression equations (Graves, 2000). Such a set of equations would be helpful for designing cross-drain placement and buffer-zone layout to minimize the impacts of sediment from roads on streams. 


\section{Method}

The basic road template for this study was simple with three road elements: travelway, fillslope, and forest buffer (Figure 1). The cutslope and hillslope above the travelway were assumed to contribute a negligible amount of runoff. The travelway was considered flat or outsloping. A broad suite of the road, fill, and buffer lengths and slopes was selected (Table 1).

The management file was built to reflect activity on a standard road that gets regular traffic and is maintained by

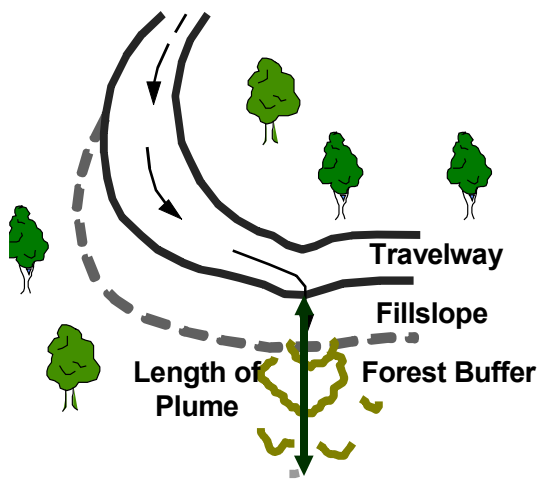

Figure 1. Diagram of the road scenario: 1. travelway, 2. fillslope, 3 . forest buffer blading, once every year (Elliot and Hall 1997). The road had a shoulder with little traffic and a fillslope covered in grasses and shrubs. The buffer or forest floor, is

Table 1. Topographic inputs.

\begin{tabular}{lllllll}
\hline Road length (m) & 10 & 20 & 22 & 40 & 60 & 100 \\
Road slope (\%) & 2 & 4 & 8 & 9 & 16 & \\
Buffer Length (m) & 0 & 10 & 40 & 80 & 200 & \\
Buffer slope (\%) & 4 & 10 & 25 & 60 & & \\
\hline
\end{tabular}

covered with a 20-year-old stand of timber and its residue.

Five generic soil files were developed to describe the basic soil types observed in the field (Table 2). These soils ranged from fine to coarse grained and include two soils to describe gravel surfacing.

Thirty-year long climate files were generated using the CLIGEN weather simulator. Thirty-three climates were selected to represent the major forested ecoregions of the United States (Table 3).

\section{Creation of the WEPP Database}

A batch file was written to carry out successive WEPP runs and collect only required information from the output files. The resulting database provided information about the amount of sediment generated by various road templates as well as all the key input parameters.

\section{Correlation analysis}

A Pearson correlation analysis was carried out to assist with the selection of regression variables. It was also used to see how closely the three dependent variables (total runoff, road soil loss, and buffer sediment yield) were related. The 
Table 2. Soil properties of the different road soils and slope segments used in this study.

\begin{tabular}{|c|c|c|c|c|c|c|}
\hline $\begin{array}{l}\text { Soil Type } \\
\text { USCS }\end{array}$ & & $\begin{array}{l}\text { Clay } \\
\text { CL }\end{array}$ & $\begin{array}{l}\text { Silt } \\
\text { ML }\end{array}$ & $\begin{array}{l}\text { Sand } \\
\text { S-SL }\end{array}$ & $\begin{array}{l}\text { Clay } \\
\text { Gravel } \\
\text { CG }\end{array}$ & $\begin{array}{l}\text { Sand } \\
\text { Gravel } \\
\text { SP-SG }\end{array}$ \\
\hline \multirow[t]{9}{*}{ Road } & Thickness & 200 & 200 & 200 & 200 & 200 \\
\hline & \%Gravel & 20 & 5 & 5 & 60 & 80 \\
\hline & $\%$ Sand & 30 & 30 & 60 & 40 & 70 \\
\hline & $\%$ Clay & 30 & 15 & 5 & 20 & 5 \\
\hline & K sat & 0.3 & 0.3 & 1 & 2 & 3 \\
\hline & $\mathrm{Ki}$ & 1000000 & 3000000 & 2000000 & 1000000 & 2000000 \\
\hline & $\mathrm{Kr}$ & 0.002 & 0.0006 & 0.0004 & 0.0003 & 0.0003 \\
\hline & $\mathrm{Tc}$ & 1.5 & 1.8 & 2 & 1.8 & 2 \\
\hline & Organics \% & 0.01 & 0.01 & 0.01 & 0.01 & 0.01 \\
\hline \multirow[t]{8}{*}{ Fillslope } & $\%$ Gravel & 20 & 5 & 5 & 40 & 40 \\
\hline & $\%$ Sand & 30 & 30 & 60 & 35 & 65 \\
\hline & $\%$ Clay & 30 & 15 & 5 & 25 & 5 \\
\hline & k sat & 5 & 8 & 10 & 25 & 40 \\
\hline & $\mathrm{Ki}$ & 1000000 & 3000000 & 2000000 & 1000000 & 2000000 \\
\hline & $\mathrm{Kr}$ & 0.0002 & 0.0006 & 0.0004 & 0.00025 & 0.00035 \\
\hline & $\mathrm{Tc}$ & 1.5 & 1.8 & 2 & 1.6 & 2 \\
\hline & Organics \% & 2 & 2 & 2 & 2 & 2 \\
\hline Buffer & $\%$ Gravel & 20 & 5 & 5 & 20 & 5 \\
\hline \multirow[t]{7}{*}{ Forest floor } & $\%$ Sand & 30 & 30 & 60 & 30 & 60 \\
\hline & $\%$ Clay & 30 & 15 & 5 & 30 & 5 \\
\hline & k sat & 10 & 15 & 20 & 50 & 80 \\
\hline & $\mathrm{Ki}$ & 1000000 & 3000000 & 2000000 & 1000000 & 2000000 \\
\hline & $\mathrm{Kr}$ & 0.0002 & 0.0006 & 0.0004 & 0.0002 & 0.0004 \\
\hline & $\mathrm{Tc}$ & 1.5 & 1.8 & 2 & 1.5 & 2 \\
\hline & Organics \% & 4 & 4 & 4 & 4 & 4 \\
\hline
\end{tabular}

correlation analysis was run on the entire WEPP output set, then correlations were run by soil and by ecoregion.

Road soil loss was most highly correlated with road total runoff, followed by the buffer sediment yield, road length, and annual precipitation. When the correlations were done by soil and climate the relationships were similar with road gradient added to the list. From these analyses it appears that the total runoff from the road and sediment yield from the profile were the most highly correlated variables to road soil loss. Variations of road length and road gradient were the most important independent variables in the correlation analysis.

Road total runoff had a similar correlation coefficient matrix, with soil loss from the road and precipitation ranking the highest, followed by road length, sediment yield, and elevation. The ranking was the same for the correlation analysis 
done by soil type. The correlation analysis done by climate indicated that soil should be added to the list.

Sediment yield from the buffer was correlated to road soil loss and road total runoff. When the correlations were done by soil, road length, and precipitation were added to the list of correlated variables. When correlating by ecoregion road slope also was correlated.

\section{$\underline{\text { Regression analysis }}$}

A multivariate regression analysis was conducted at three different precision levels. The first level was applied to the entire data set (72,900 lines) and included all of the climate and soil descriptors. Regression performed at this level had very low $\mathrm{R}^{2}$ values (0.5) and high mean square error (MSE). The second level of regression divided the data set into the 31 categories by the ecoregions represented in the 33 climates. This level had better results with $\mathrm{R}^{2}$ values around 0.7 yet still had a high MSE. The third level of regression was, by soil and ecoregion (155 categories) and had $\mathrm{R}^{2}$ of $0.9+/-0.05$ and MSE of 0.5 .

The regressions were done with different models as well: a main effects model, a main effects with interactions model, and a quadratic model. From each of those regression models, the ten variables or variable sets that most influenced the regression equations were considered for a final regression or User-Defined model.

This procedure was repeated for soil loss from the road, runoff from the road, and sediment yield from the profile. Finally, new data set resulting from the regression equation calculations was graphically compared to the original WEPP output used for the regression to see how well the equation fit the WEPP output data (Graves, 2000).

\section{Road Soil Loss}

The first regression analysis was calculated to estimate the road soil loss. The resulting regression equation had an $\mathrm{R}^{2}$ of 0.9914 and a MSE of 0.0812 :

$$
\begin{aligned}
& \log 10(\mathrm{SLSR})=-0.066+(\mathrm{ECOREG})+(\mathrm{SOL})-12 \times 10^{-5} *(\mathrm{RL})^{2}+0.0389 *(\mathrm{RL})+ \\
& 9.243 *(\mathrm{RS})-0.063 *(\mathrm{RLRS})-24 \times 10^{-5}(\mathrm{RLORS})-47.66 *(\mathrm{RSORL}) \\
& \text { Where: }
\end{aligned}
$$

SLSR $=$ Soil loss from the road $(\mathrm{kg} / \mathrm{m}$ road width $)$

$\mathrm{RL}=$ Road length $(\mathrm{m})$

$\mathrm{RS}=$ Road Slope (percent)

RLRS $=$ Road length times road gradient ( $\mathrm{m} *$ percent)

RLORS $=$ Road length divided by road gradient $(\mathrm{m} /$ percent $)$

RSORL $=$ Road gradient divided by road length (percent $/ \mathrm{m}$ )

ECOREG = Ecoregion (Table 3)

$\mathrm{SOL}=$ Soil type (Table 4$)$

The erosion predicted by equation (1) was graphed against the original WEPP output set (Figure 2). This figure showed a fairly tight distribution of points running 
along the one-to-one line, with increasing variance as the values become larger. About $86 \%$ of the points were inside the $+/-25 \%$ envelope and approximately $98 \%$ lie with in $+/-50 \%$ envelope (S.R.M.Graves, 2000).

Soil loss from the road predicted by Regression Vs Soil loss from the road predicted by WEPP

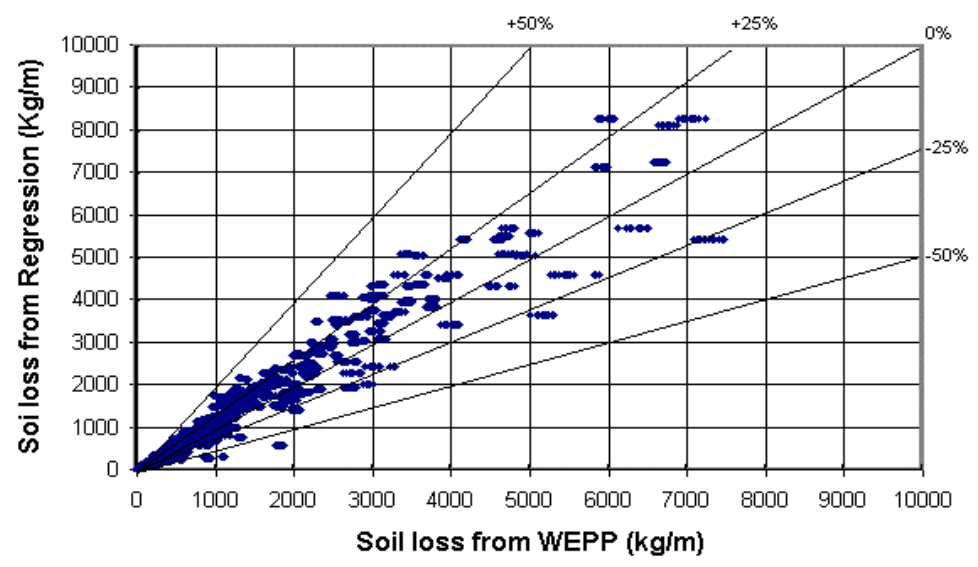

Figure 2. Figure of the regression derived road soil losses vs. the WEPP derived road soil loss.

\section{Road total runoff from the road}

Road total runoff was derived in a manner similar to that used to develop the road soil loss regression equation. This equation had an $\mathrm{R}^{2}$ value of 0.9842 and a MSE of 0.0699 , both indicating a good regression model: $*(\mathrm{RL})^{2}$

$\log 10($ TROV $)=-0.081+($ ECOREG $)+(\mathrm{SOL})+2.91 \times 10^{-6} *(\mathrm{RL})^{3}-6.0 \times 10^{-4}$

$+0.0444 *(\mathrm{RL})+0.456 *(\mathrm{RS})$

Where:

TROV $=$ Total runoff volume from the $\mathrm{road}\left(\mathrm{mm} / \mathrm{m}^{2}\right.$ of road $)$

$\mathrm{RL}=$ Road length (m)

$\mathrm{RS}=$ Road gradient (percent)

ECOREG = Ecoregion (Table 3)

$\mathrm{SOL}=$ Soil (Table 4)

The total runoff regression equation then was used to calculate a new output set to compare with the WEPP output set (Figure 3). This graph had a tight cloud of data points rising at a one-to-one slope. There was a distinctive pattern to the cloud that appears to be associated with road length. This indicated that under some circumstances the road coefficient was not quite correct. About $81 \%$ of the values were within $+/-50 \%$ of the WEPP output values, and $60 \%$ were within $+/-25 \%$. When runoff values less than $5 \mathrm{~mm}$ per year were excluded from the output sets, $82 \%$ of the data points were within $+/-25 \%$ and $97 \%$ were within $+/-50 \%$ (Graves, 2000). 


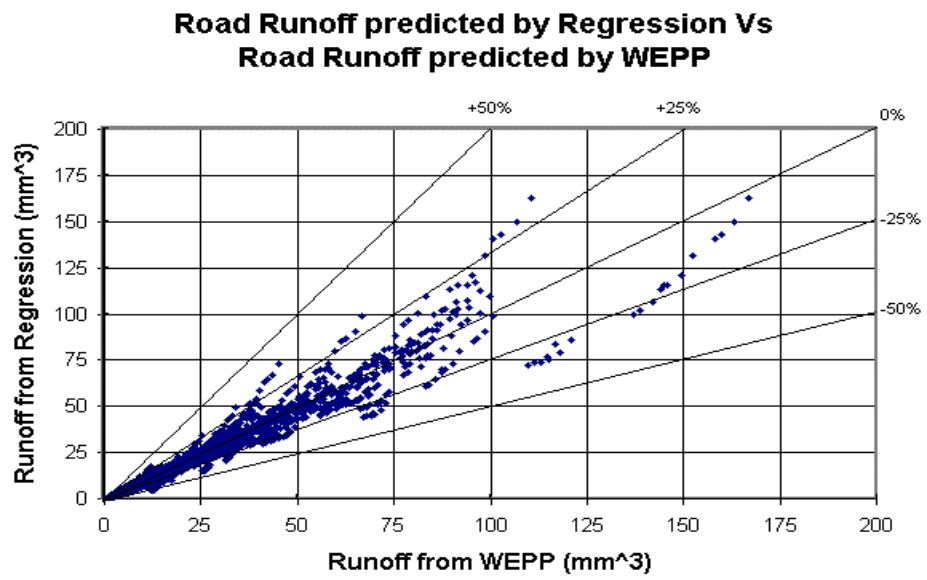

Figure 3. Regression runoff versus the WEPPpredicted runoff from the road

\section{Sediment yield from the buffer}

Finding an equation to estimate sediment yield from the buffer was more challenging than finding a model to estimating road soil and runoff. This variable depended on both the soil from the road and runoff from the road. Thus, it was important that those variables were estimated well. It also depended on the buffer topographic and soil conditions.

Various methods were investigated to alleviate this problem. Finally, an equation was derived by adding one $\mathrm{kg}$ to all of the sediment yield values, eliminating the problem of zero and near-zero values. This equation provided the best results, but still appeared to be underestimating sediment yield. This could be due to the fact that many of the WEPP predicted sediment yields were zero, potentially skewing heavily the regression results low. Or, it is possible that the values found using the equations for road soil loss and road runoff were causing a underestimation in the sediment yield equation.

The final equation for sediment yield from the profile had eight variables:

$$
\begin{aligned}
& \log 10(\text { SYPLUS })=-0.716+(\text { ECOREG })+(\text { SOL })-9.361 *(B S O B L)+ \\
& 1.664 *(B S)+4.841 *(\log (10) \text { SLSR } / \text { BL })+0.251 *((\log (10) S L S R) * \\
& (\log (10) \text { TROV }))
\end{aligned}
$$

Where:

SYPLUS = Sediment yield from profile plus one $\mathrm{kg}(\mathrm{kg} / \mathrm{m}$ width $)$ BSOBL $=$ buffer gradient over buffer length (percent $/ \mathrm{m}$ length)

$\mathrm{BS}=$ Buffer gradient (percent)

$\log (10) \mathrm{SLSR} / \mathrm{BL}=\log (10)$ value of road soil loss divided by Buffer length $((\mathrm{kg} / \mathrm{m}$ width of road $) /(\mathrm{m}$ length of buffer $))$

$\log (10)$ SLSR $* \log (10)$ TROV $=\log (10)$ of road soil loss times $\log (10)$ of the road total runoff, $\left((\mathrm{kg} / \mathrm{m}\right.$ width of road $) *\left(\mathrm{~mm} / \mathrm{m}^{2}\right.$ road $\left.)\right)$ ECOREG $=$ Ecoregion $($ Table 3$)$ 


$$
\mathrm{SOL}=\text { Soil type (Table } 4)
$$

This equation had an $\mathrm{R}^{2}$ value of 0.8323 and a Root MSE of 0.2998 (figure 4). However, when the output data set was plotted against the WEPP output set, the regression equation appeared to under-predicted the sediment yield much of the time. Only about $32 \%$ lie within $+/-25 \%$ and 47 within $50 \%$. This was disappointing, it is apparent that more factors contribute to the transport and delivery of sediment across a buffer strip than what was available for these regression equations.

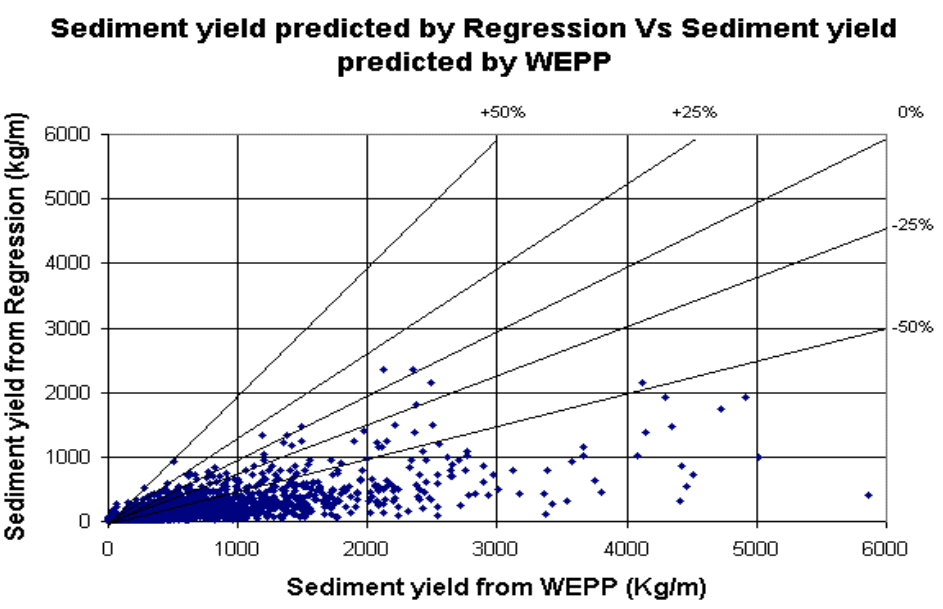

Figure 4. The Figure of the regression calculated data and the WEPP derived data.

\section{Summary}

This study was to provide a versatile working tool to allow forest road planers to estimate erosion from forest roads to assist with road planing and placement of cross-drain structures. The road soil loss and total road runoff equations were successful in this goal. Both of these equations described the WEPP-predicted database reasonably well.

The Sediment yield equation that would have provided insight into road location and volumes of sediment reaching sensitive areas was less successful. These values under predicted the larger volumes of sediment by almost a half, while road configurations with low sediment yields were fairly close to the WEPP derived numbers. 
Table 3. Ecoregions, climates, and regression coefficients

\begin{tabular}{|c|c|c|c|c|}
\hline Ecoregion & Location of climate & $\begin{array}{l}\text { Coefficients for } \\
\text { Road soil loss }\end{array}$ & $\begin{array}{l}\text { Coefficients for } \\
\text { Road total runoff }\end{array}$ & $\begin{array}{l}\text { Coefficients for } \\
\text { Sediment yield }\end{array}$ \\
\hline $\mathrm{m} 242 \mathrm{a}$ & Sappho WA & 0.865 & 0.591 & 0.66 \\
\hline $\mathrm{m} 242 \mathrm{~b}$ & Packwood WA & 0.417 & 0.34 & 0.492 \\
\hline $\mathrm{m} 333 \mathrm{a}$ & Colville WA & -0.317 & -0.568 & 0.137 \\
\hline $\mathrm{m} 242 \mathrm{a}$ & North Bend OR & 0.865 & 0.591 & 0.66 \\
\hline $\mathrm{m} 242 \mathrm{c}$ & Wickiup OR & -0.387 & -0.36 & 0.418 \\
\hline $\mathrm{m} 332 \mathrm{~g}$ & Austin OR & -0.587 & -0.541 & 0.221 \\
\hline $\mathrm{m} 261 \mathrm{~g}$ & Alturas CA & -0.593 & -0.609 & 0.0035 \\
\hline $\mathrm{m} 261 \mathrm{~b}$ & Willits CA & 0.717 & 0.446 & 1.013 \\
\hline $262 \mathrm{a}$ & Glenville CA & 0.0351 & -0.108 & 0.486 \\
\hline $\mathrm{m} 333 \mathrm{~d}$ & Wallace ID & 0 & 0 & 0 \\
\hline $\mathrm{m} 332 \mathrm{a}$ & Deadwood Dam ID & -0.387 & -0.093 & 0.0593 \\
\hline $342 b$ & Tuscarora NV & -0.554 & -0.747 & 0.336 \\
\hline $\mathrm{m} 333 \mathrm{~b}$ & Libby MT & -0.369 & -0.573 & 0.32 \\
\hline $\mathrm{m} 332 \mathrm{~b}$ & Seely MT & -0.316 & -0.467 & 0.197 \\
\hline m331a & Lake Yellowstone WY & -0.456 & -0.611 & 0.115 \\
\hline m331d & Heber UT & -0.485 & -0.531 & 0.241 \\
\hline $\mathrm{m} 313 \mathrm{a}$ & Heber AZ & 0.0242 & -0.197 & 0.579 \\
\hline m331h & Eagle CO & -0.523 & -0.801 & 0.315 \\
\hline m331f & Taos NM & -0.274 & -0.541 & 0.294 \\
\hline $331 f$ & Fort Meade SD & 0.198 & -0.147 & 0.601 \\
\hline $212 j$ & Watersmeet MI & 0.317 & 0.0277 & 0.446 \\
\hline $222 a$ & Salem MO & 0.594 & 0.287 & 0.555 \\
\hline $231 \mathrm{~g}$ & Clarksville AR & 0.707 & 0.392 & 0.558 \\
\hline $231 \mathrm{e}$ & Lufkin TX & 0.772 & 0.419 & 0.762 \\
\hline $231 \mathrm{e}$ & Ruston LA & 0.772 & 0.419 & 0.762 \\
\hline $231 \mathrm{c}$ & Birmingham AL & 0.765 & 0.432 & 0.645 \\
\hline $221 \mathrm{e}$ & New Lexington $\mathrm{OH}$ & 0.453 & 0.157 & 0.346 \\
\hline $221 \mathrm{~h}$ & Heidelberg KY & 0.588 & 0.296 & 0.525 \\
\hline $\mathrm{m} 221 \mathrm{~d}$ & Cullowhee NC & 0.6 & 0.341 & 0.61 \\
\hline $\mathrm{m} 221 \mathrm{c}$ & Lewisburg WV & 0.413 & 0.158 & 0.379 \\
\hline $212 \mathrm{~g}$ & RidgewayPA & 0.393 & 0.127 & 0.433 \\
\hline $\mathrm{m} 212 \mathrm{a}$ & Lancaster NH & 0.282 & 0.028 & 0.298 \\
\hline $\mathrm{m} 244 \mathrm{c}$ & Juneau AK & 0.391 & 0.225 & 0.0809 \\
\hline
\end{tabular}

Table 4. Regression coefficients for soil types

\begin{tabular}{cccc}
\hline Soil types & $\begin{array}{c}\text { Soil coefficients } \\
\text { Road soil loss }\end{array}$ & $\begin{array}{c}\text { Soil coefficients road } \\
\text { total runoff }\end{array}$ & $\begin{array}{c}\text { Soil coefficients sediment } \\
\text { yield from profile }\end{array}$ \\
\hline clay gravel & 0.0204 & 0.13 & -0.218 \\
clay & -0.027 & 0.278 & 0.212 \\
sand gravel & -0.03 & -0.01 & -0.496 \\
silt & 0.276 & 0.185 & 0.116 \\
sand & 0 & 0 & 0 \\
\hline & & 9
\end{tabular}




\section{$\underline{\text { References }}$}

Burroughs, Jr., E. R. and J. G. King. 1989. Reduction of soil erosion on forest roads. Ogden, UT:U.S. Department of Agriculture, Forest Service, Intermountain Research Station. Gen. Tech. Rep. INT-264. 21 p.

Copstead et al.,1997. Water Roads Interaction: Relief Culverts. Water/Road Interaction Technology Series, Publication 9777 1812.Washington D.C.: USDA, Forest Service, Technology \& Development Program. 7p.

Elliot, W. J., and D. E. Hall. 1997. Water Erosion Prediction Project (WEPP) forest applications. General Technical Report INT-GTR-365. Ogden, UT: USDA Forest Service, Rocky Mountain Research Station. 11 pp.

Elliot, W. J., D. E. Hall, and D. L Scheele. 2000. Forest Service Interfaces for the Water Erosion Prediction Project Computer Model [Online]. Available: http://forest.moscowfsl.wsu.edu/fswepp/ [Feb 10, 2000].

Flanagan, D. C., and S. J. Livingston. 1995. WEPP User Summary. NSERL Report No. 11, W. Lafayette, IN: National Soil Erosion Research Laboratory. 131 pp.

Graves, S. R. M. 2000. Using the WEPP model to derive regression equations to predict soil loss and runoff from roads and sediment yield acrossed forested buffers. Master of Science Thesis. Moscow ID: University of Idaho.

Morfin, S. R., W.J. Elliot, R. Foltz, and S. Miller. 1996. Predicting effects of climate, soil and topography on road erosion with WEPP. Presented at the 1996 International Meeting of the American Society of Agricultural Engineers, Paper No. 965016. St. Joseph, MI: ASAE.

Tysdal, L. M., W. J. Elliot, C. H. Luce, and T. A. Black. 1999. Modeling erosion from insloping low-volume roads with WEPP watershed model. Transportation Research Record. Washington, D.C.:Transportation Research Board, National Research Council. 2(1652):250-256.

\section{About the Authors}

Susan Graves is a Civil Engineer with the Nez Perce National Forest, Route 2, Box 475, Grangeville, ID 83530. email: sgraves@fs.fed.us

Bill Elliot is the Project Leader of the Soil and Water Engineering Research Work Unit of the Rocky Mountain Research Station, 1221 South Main, Moscow, ID 83843. email: welliot@fs.fed.us 


\section{Rocky Mountain}

This paper was published as:

Graves, S.R.; Elliot, W.J. 2000. Road erosion estimation equations derived using a WEPP database. In: Flug, M.; Frevert, D.; Watkins, Jr., D.W., eds., Watershed Management \& Operations Management 2000; 2000 June 2024; Fort Collins, CO. Reston, VA: American Society of Civil Engineers: 10 p. Keywords:

$2000 \mathrm{~b}$

Moscow Forestry Sciences Laboratory

Rocky Mountain Research Station

USDA Forest Service

1221 South Main Street

Moscow, ID 83843

http://forest.moscowfsl.wsu.edu/engr/ 